\title{
High Level of Serum CholesterylEsterTransferProtein and Chemerin as a Risk Factor of Metabolic Syndrome in Adolescent Obese and the Description of Cholesteryl Ester Transfer Protein -629c/A Gene Promoter Polymorphism
}

\author{
I. Made Arimbawa ${ }^{1}$, Ketut Suastika ${ }^{2}$, I. Ketut Junitha ${ }^{3}$, I. Wayan Bikin Suryawan ${ }^{4}$, Michelle Husin $^{1 *}$ \\ ${ }^{1}$ Department of Child Health, Sanglah General Hospital, Faculty of Medicine, Udayana University, Denpasar, Indonesia; \\ ${ }^{2}$ Department of Internal Medicine, Sanglah General Hospital, Faculty of Medicine, Udayana University, Denpasar, Indonesia; \\ ${ }^{3}$ Department of Biology, Faculty of Mathematic and Natural Sciences, Udayana University, Denpasar, Indonesia; ${ }^{4}$ Department \\ of Child Health, Wangaya General Hospital, Denpasar, Indonesia
}

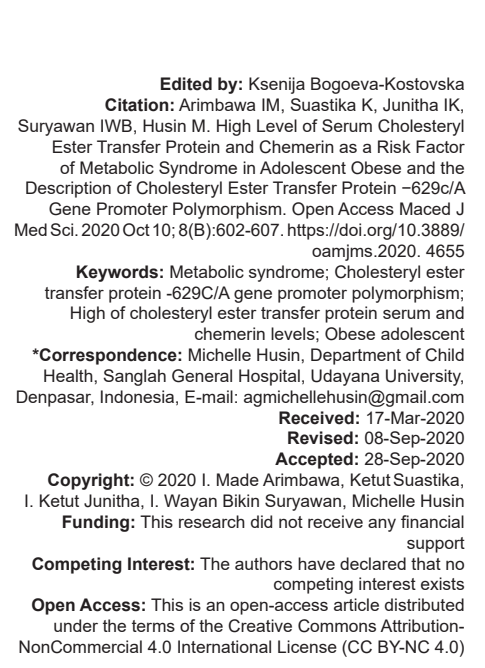

\section{Introduction}

The World Health Organization states that overweight and obesity in children and adolescents are public health problems throughout the world. Obesity is strongly associated with insulin resistance (IR) and is the underlying factor in the occurrence of the metabolic syndrome (MS). Thus, MS is a group of risk factors associated with IR that the highest prevalence found in obese individuals. Hence, the prevalence of MS in children and adolescents has increased, along with increasing incidence of obesity.

The prevalence of obesity in children and adolescents is increasing rapidly throughout the world. According to the National Health and Nutrition
Examination Survey, in $2011-2012,16.9 \%$ of children aged $2-19$ years, and $34.9 \%$ of adults aged 20 years or over were obese [1], but the overall prevalence of obesity among children and adolescents remained unchanged compared to 2009-2010 (16.9\%) and there were no significant changes from 2003 to 2004 [2]. According to the Riset Kesehatan Dasar (Riskesdas) 2013 Ministry of Health's, it showed that national overweight and obesity problems in children aged 5-12 years amounted to $10.8 \%$ and $8.8 \%$, respectively, already close to the estimated world numbers in 2020 (9.1\%). In adolescents aged 13-15 years, the prevalence of obesity is $10.8 \%$ with $8.3 \%$ obese and $2.5 \%$ very obese [3]. The prevalence of obesity at Denpasar in 2002 was $11 \%$ in adolescents $11-17$ years [4], while in Bali, Dewi and Sidiartha found the prevalence of obesity was $15 \%$ in children aged $10-12$ years [5]. 
MS is a cluster of the following risk factors: Abdominal obesity, hypertension, hypertriglyceridemia, fasting plasma glucose levels, and low level of high-density lipoprotein cholesterol (HDL-C) [6]. This combination is considered as a precursor to cardiovascular disease and type 2 diabetes mellitus (type $2 \mathrm{DM}$ ). Several studies on the prevalence of MS in overweight and obese children have been carried out in Indonesia. Research in Jakarta found that the prevalence of MS was $34 \%$ in 50 obese teenagers aged 10-19 years [7], [8]. Dwipayana et al. got that the prevalence of adult age in Bali at MS was $18.2 \%$ (male, $16.6 \%$; female, 20.0\%) [8].

Some single-nucleotide polymorphisms (SNPs) are significantly associated with overall components of MS including, TCF7I2, LPL, APOA5, cholesteryl ester transfer protein (CETP), and APOC1/APOE/TOMM40 [9]. CETP is a glycoprotein that containing 476 amino acids with a molecular weight of $74 \mathrm{kDa}$ has an important role in plasma lipoprotein remodeling [10]. CETP facilitates the absorption of cholesterol from peripheral tissue to the liver in a process known as reverse cholesterol transport [11]. At the same time, CETP transfers cholesterol esters from HDL to low-density lipoprotein (LDL) and very low-density lipoprotein (VLDL) together with triglyceride (TG) exchanges. Therefore, CETP can increase the atherogenicity of apoBcontaining lipoproteins and negatively affect the HDL levels [12], [13].

Chemerin is one of the new adipokines reported in 2003, which is a chemoattractant that plays role in the inflammatory process [14]. Chemerin is secreted by adipose tissue in an inactive form as prochemerin, then activated by proteolytic protease enzymes which then work on $\mathrm{G}$ protein-coupled receptors CMKLR1 (chemokine receptor-like 1) on macrophages and dendritic cells [15]. Chemerin has an important role in the pathophysiology of obesity and BC [16], [17].

\section{Materials and Methods}

This study was a matched-pair case control and conducted on adolescent in junior and senior high school, Denpasar, Prodia ${ }^{\circledR}$ Laboratory, Clinical Pathology Laboratory, Medical Faculty, Udayana University/Sanglah Hospital, Unit Laboratorium Biomedik Terpadu, Medical Faculty, Unud, and Genetic Science Laboratory, Jakarta, after approved by Research Ethics Committee Medical Faculty, Udayana University/Sanglah Hospital, Denpasar. Research time was from May 2017 to December 2017.

The target population in our study were people ages 11-18 years with obesity in Bali, while the accessible population are obese adolescents in selected junior and high school ages 11-18 years in the city of Denpasar during the study period. The sample was part of an accessible population that met the inclusion and exclusion criteria (Figure 1). The sample for the case is adolescents obese with metabolic syndrome (MS obese) and the sample for control is obese adolescents without metabolic syndrome (non-MS obese). The selection of samples in our study was consecutive sampling technique, where all existing samples and fulfilling the research criteria were included in the study until the required number of sample was fulfilled. Sample size was calculated based on $\alpha=0.05$ and $(\beta)=10 \%$. Based on the results, final sample size was 35 sample for each group.

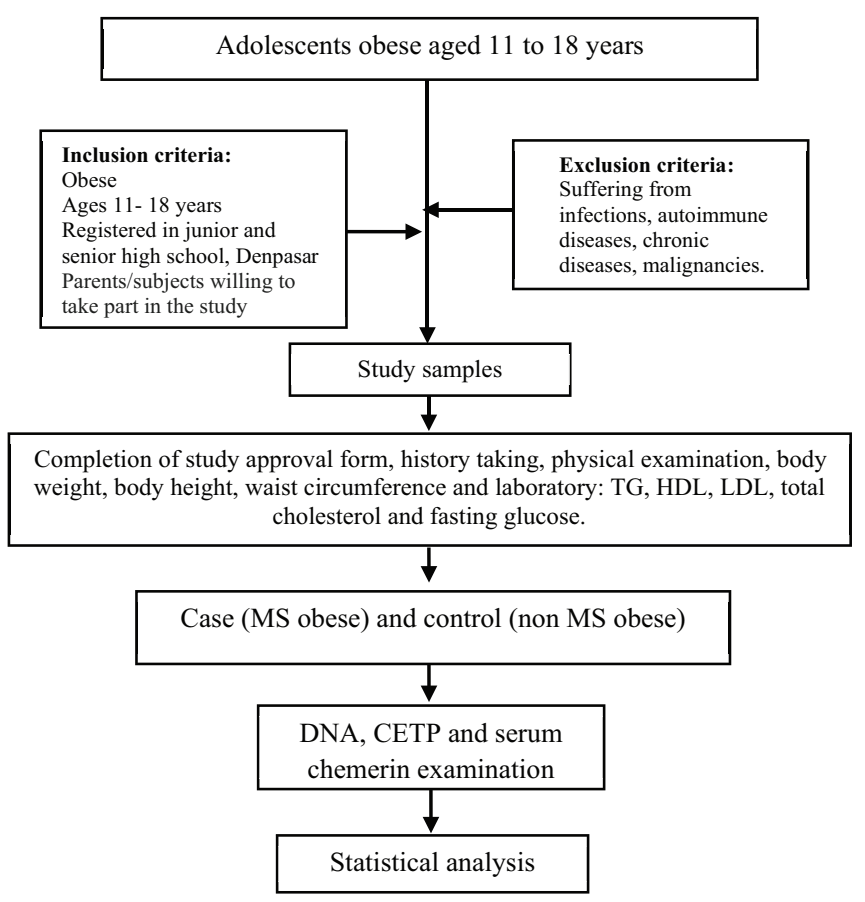

Figure 1: Study algorithm

The difference in output between the subject characteristic variables and genotype variant CETP $-629 \mathrm{C} / \mathrm{A}$ polymorphism (AA, CA, and CC genotype) is tested by ANOVA or Kruskal-Wallis if it did not meet the normality. The differences in genotype of CC, CA, and AA in CETP -629C/A polymorphisms and the differences in frequency of $A$ and $C$ alleles to MS risk, the relationship between plasma CETP/chemerin levels with MS risk, are tested by the Chi-squared test. The CETP and chemerin levels must a nominal dichotomy, so the cutoff point is determined by a diagnostic test. Confounding variables were controlled by multivariate logistic regression analysis. The variable included in the multivariate analysis was type $2 \mathrm{DM}$ family history. The final result of logistic regression is OR $(\mathrm{Cl}[95 \%$ confidence interval]). $p<0.05$ was used as the limit of significance.

This study was approved by Research Ethics Committee Medical Faculty, Udayana University/ Sanglah Hospital, Denpasar. 


\section{Results}

There were 542 students attended to the counseling of the children and adolescents about obesity and metabolic syndrome. To students who appear clinically obese, was advised to take part in the study and given informed consent sheet, then submitted to each parents for participation approval. A total of 147 students were performed physical and laboratory tests to get subjects that met the inclusion criteria. Case group was 43 subjects obese adolescents with MS and control group was obese 43 subjects adolescents without MS (Table 1).

In both groups, there were more boys than girls (boys 25 subjects and girls 18 subjects). Three adolescents in each group have not reached puberty yet. There were statistically significant differences in some characteristic variables between the two groups, including TG and HDL-C levels in cases (MS obese) and controls (non-MS obese) ( $p<0.001)$. Significant differences were also found in family history of type $2 \mathrm{DM}$ between MS obese and non-MS obese groups ( $p=0.034)$, then bivariate and multivariate analysis were carried out.

The relationship of the subject characteristics between both groups and $A A, C A$, and $C C$ genotypes from CETP -629C/A gene promoter polymorphism is shown in Table 2. There were no significant differences between AA, $\mathrm{CA}$, and $\mathrm{CC}$ genotype in all subject characteristics variables such as body mass index (BMI), waist circumference (WC), HDL-C, TG, BW, BH, systolic and diastolic blood pressure, fasting blood sugar, and serum CETP levels.

Based on genotype frequencies, CETP gene in promoter region $-629 \mathrm{C} / \mathrm{A}$, it was found that CETP -629 AA gene genotype was less in the MS obese group than
non-MS obese (six subjects in the MS obese group and seven subjects in the non-MS obese group). Bivariate analysis found that AAgenotypes and CA genotypes were not MS risk factors when compared to CC genotypes (OR $=0.81$ [95\% Cl 0.23-2.88], $p=0.75$ and $O R=0.95$, respectively [95\% Cl 0.38-2.37] $p=0.91$ ) (Tables 3-4).

Based on allele frequency, there was no significant difference between individual carriers A allele in MS obese groups and non-MS obese with individual carriers $\mathrm{C}$ allele to risk of $\mathrm{MS}(\mathrm{OR}=0.91$ [95\% Cl 0.39 2.14], $p=0.83$ ) (Table 3).

The researcher determined cutoff point value by dividing CETP levels into high and normal levels by considering optimal sensitivity and specificity. CETP levels of $\geq 2 \mu \mathrm{g} / \mathrm{mL}$ considered as high and $<2 \mu \mathrm{g} / \mathrm{mL}$ considered as normal, with a sensitivity value of $72.1 \%$ and specificity of $60.5 \%$ (Figure 2). The value of area under curve (AUC) was 0.697 (69.7\%) (weak). Cutoff point of the chemerin $\geq 170 \eta \mathrm{g} / \mathrm{mL}$ considered as high level and $<170 \mathrm{ng} / \mathrm{mL}$ considered as normal, with a sensitivity $74.4 \%$ and a specificity $58.1 \%$ (Figure). The value of AUC was 0.704 (70.4\%) (moderate).

Based on CETP levels, it was found that subjects with high levels of CETP were more in MS obese group compared to non-MS obese group (31 MS obese subjects and 17 non-MS obese subjects). Bivariate analysis with the Chi-squared test found that high levels of CETP were MS risk factors (OR = 3.95 [95\% Cl 1.60-9.76], $p=0.0002$ ) (Table 4).

Based on the chemerin level, it was found that the subjects with high levels of chemerin were more in MS obese group compared than non-MS obese group. Bivariate analysis with the Chi-square test showed risk

Table 1: Subject characteristics

\begin{tabular}{|c|c|c|c|}
\hline Variable & MS obese $(n=43)$ Mean \pm SD or Median (min-max) & Non-MS obese $(n=43)$ Mean \pm SD or Median (min-max) & $\mathrm{p}$ \\
\hline Age (year) & $16(12-18)$ & $16(12-17)$ & $0.951^{\circ}$ \\
\hline Gender (boy/girl) & $25 / 18$ & $25 / 18$ & $1.000^{\mathrm{a}}$ \\
\hline $\mathrm{BW}(\mathrm{kg})$ & $88(62-108)$ & $85(60-103)$ & $0.231^{\circ}$ \\
\hline $\mathrm{BH}(\mathrm{cm})$ & $164(147-175)$ & $161(145-173)$ & $0.111^{\mathrm{c}}$ \\
\hline $\mathrm{BMI}\left(\mathrm{kg} / \mathrm{m}^{2}\right)$ & $32.99(24.84-38.1)$ & $33.09(28.54-38.48)$ & $0.678^{\circ}$ \\
\hline $\mathrm{C}(\mathrm{cm})$ & $97.56( \pm 7.69)$ & $96.64( \pm 7.59)$ & $0.581^{\mathrm{b}}$ \\
\hline LBW history, n (\%) & $2(4.7)$ & $5(13.15)$ & $0.237^{\mathrm{a}}$ \\
\hline Type 2 DM history in family $\mathrm{n}(\%)$ & $13(30.2)$ & $5(11.6)$ & $0.034^{\mathrm{a}}$ \\
\hline Puberty state $n(\%)$ & $40(93)$ & $40(93)$ & $1.000^{\mathrm{a}}$ \\
\hline Systolic BP (mmHg) & $110(100-130)$ & $110(100-130)$ & $0.052^{\circ}$ \\
\hline Diastolic BP (mmHg) & $70(70-95)$ & $70(70-80)$ & $0.170^{c}$ \\
\hline Fasting glucose (mg/dL) & $91(75-191)$ & $89(71-102)$ & $0.452^{\mathrm{c}}$ \\
\hline $\mathrm{TG}(\mathrm{mg} / \mathrm{dL})$ & $156(95-328)$ & $84(37-122)$ & $<0.001^{\circ}$ \\
\hline $\mathrm{HDL}-\mathrm{C}(\mathrm{mg} / \mathrm{dL})$ & $41.33( \pm 8.56)$ & $52.42( \pm 8.34)$ & $<0.001^{b}$ \\
\hline CETP $(\mu \mathrm{g} / \mathrm{mL})$ & $2.30(1.27-7.6)$ & $1.86(1-6.87)$ & $0.002^{c}$ \\
\hline Chemerin (ng/L) & $215.20(100.77-805.44)$ & $167.82(80.73-724.08)$ & $0.002^{c}$ \\
\hline
\end{tabular}

Table 2: Relationship between subject characteristics and genotype variant of polymorphism CETP -629C/A

\begin{tabular}{|c|c|c|c|c|}
\hline Value & AA Mean \pm SD or median (min-max) & CA Mean \pm SD or median (min-max) & CC Mean \pm SD or Median (min-max) & $\mathrm{p}$ \\
\hline IMT $\left(\mathrm{kg} / \mathrm{m}^{2}\right)$ & $31.75 \pm 2.2$ & $33.28 \pm 2.05$ & $33.26 \pm 2.8$ & $0.126^{\mathrm{a}}$ \\
\hline$W C(\mathrm{~cm})$ & $96 \pm 8.5$ & $96.1 \pm 6.2$ & $98.4 \pm 8.5$ & $0.38^{\mathrm{a}}$ \\
\hline $\mathrm{HDL}(\mathrm{mg} / \mathrm{dL})$ & $51 \pm 7.7$ & $48.31 \pm 10.78$ & $44.37 \pm 9.5$ & $0.052^{\mathrm{a}}$ \\
\hline $\mathrm{TG}(\mathrm{mg} / \mathrm{dL})$ & $110(61-201)$ & $107(45-328)$ & $108(37-228)$ & $0.94^{\mathrm{b}}$ \\
\hline $\mathrm{BW}(\mathrm{kg})$ & $85(73-96)$ & $84.5(60-101)$ & $89(62-108)$ & $0.36^{\mathrm{b}}$ \\
\hline $\mathrm{BH}(\mathrm{cm})$ & $166(150-173)$ & $159.5(145-175)$ & $162(150-174)$ & $0.06^{\mathrm{b}}$ \\
\hline Systolic BP $(\mathrm{mmHg})$ & $100(100-120)$ & $110(100-130)$ & $110(100-130)$ & $0.22^{\mathrm{b}}$ \\
\hline Diastolic BP (mmHg) & $70(70-80)$ & $70(70-95)$ & $70(70-90)$ & $0.52^{\mathrm{b}}$ \\
\hline Fasting BG $(\mathrm{mg} / \mathrm{dL})$ & $91(77-108)$ & $91(71-191)$ & $90(74-134)$ & $0.94^{b}$ \\
\hline $\operatorname{CETP}(\mu \mathrm{g} / \mathrm{mL})$ & $2.02(1.2-3)$ & $2(1-4.6)$ & $2.1(1.3-7.6)$ & $0.43^{\mathrm{b}}$ \\
\hline
\end{tabular}



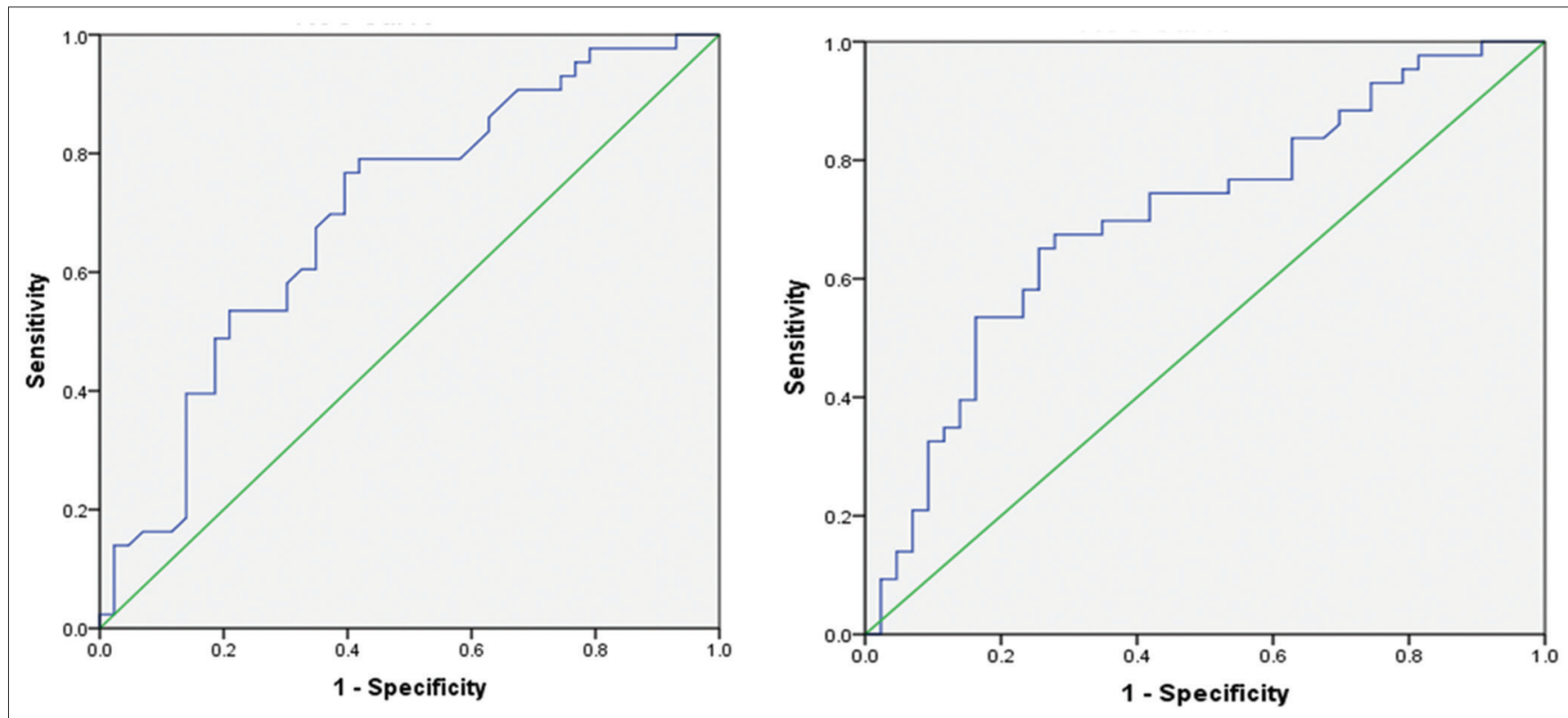

Figure 2: Receiver operating characteristic (ROC) curve CETP level (left) and chemerin level (right)

Table 3: Genotype frequency and -629C/A alleles polymorphism in MS obese and non-MS obese groups

\begin{tabular}{llllll}
\hline Genotype & SM obese & Non-SM obese & Total & OR $(95 \% \mathrm{Cl})$ & $\mathrm{p}$ \\
\hline AA & 6 & 7 & 13 & $0.81(0.23-2.88)$ & 0.75 \\
CA & 18 & 18 & 36 & $0.95(0.38-2.37)$ & 0.91 \\
CC & 19 & 18 & 37 & 1.00 & \\
Alel & & & & & \\
A & 30 & 32 & 62 & $0.91(0.39-2.14)$ & 0.83 \\
C & 56 & 54 & 110 & 1.00 & \\
\hline
\end{tabular}

of experienced MS was 4 times in chemerin high level subjects compared to normal $(\mathrm{OR}=4.04[95 \% \mathrm{Cl} 1.62-$ 10.08], $p=0.002$ ) (Table 5).

Multivariate analysis with logistic regression found that both high levels of CETP and chemerin were MS risk factors $(\mathrm{OR}=2.82$ [95\% Cl 1.07-7.41], $p=0.036 ;$ OR $=2.77[95 \%$ Cl 1.04-7.40], $p=0.042$ respectively), while the history of type $2 \mathrm{DM}$ in family did not show significant relationship (OR $=2.27[95 \%$ Cl 0.63-8.28], $p=0.212$ ) (Table 6).

\section{Discussion}

The increasing prevalence of obesity in childhood and adolescence poses a growing problem. Obese children tend not only to become obese adults but also obesity is associated with a wide range of serious complications already seen in childhood. Obese children and adults without cardiovascular risk factors have been classified as metabolic healthy obese whereas if there were already risk factors classified as metabolic unhealthy obese [18].

Table 4: Metabolic syndrome risk based on CETP serum levels

\begin{tabular}{llllll}
\hline CETP level & MS obese & Non-MS obese & Total & OR $(95 \% \mathrm{Cl})$ & $\mathrm{p}$ \\
\hline High & 31 & 17 & 48 & $3.95(1.60-9.76)$ & 0.002 \\
Normal & 12 & 26 & 38 & & \\
Total & 43 & 43 & 86 & & \\
\hline
\end{tabular}

Two risk factors MS as already mentioned in the previous studies such as gender and puberty status [19] and in our study matched have been performed. In our study, MS was more commonly found in adolescent boys (25 vs. 18). Other studies in the adult population have a higher prevalence of MS in women than in men, $29 \%$ and $23 \%$, respectively [20].

Table 5: Metabolic syndrome risk based on chemerin serum level

\begin{tabular}{llllll}
\hline Chemerin level & MS obese & Non-MS obese & Total & OR $(95 \% \mathrm{Cl})$ & $\mathrm{p}$ \\
\hline High & 32 & 18 & 50 & $4,04(1.62-10.08)$ & 0.002 \\
Normal & 11 & 25 & 36 & & \\
Total & 43 & 43 & 86 & & \\
\hline
\end{tabular}

Based on genotype CETP -629 C/A gene promoter, it was also found that there was no significant relationship between AA genotypes in both groups (MS obese and non-MS obese) compared to CC genotypes against MS risk. A study by Hou et al. found a significant differences involving frequency of genotypic distribution and alleles from rs1800775 (-629C/A), rs3764261, rs12149545, rs711752, and rs708272 between the control group and metabolic syndrome (all p < 0.05) [21]. The study was conducted in a minority adult population in China that included 571 subjects (280 patients and 291 controls). Our study did not conduct a separate analysis of the genotypic distribution of $A A, C A$, and $C C$, as well as the frequencies of $C$ and $A$ alleles between cases and controls [21].

Table 6: Multivariate logistic regression analysis of some risk factors MS

\begin{tabular}{llll}
\hline Variable & OR & $95 \% \mathrm{Cl}$ & $\mathrm{p}$ \\
\hline CETP high level & 2.82 & $1.07-7.41$ & 0.036 \\
Chemerin high level & 2.77 & $1.04-7.40$ & 0.042 \\
DMT type 2 history in family & 2.28 & $0.63-8.28$ & 0.212 \\
\hline
\end{tabular}

CETP gene polymorphism is consistently associated with HDL-C levels, but this does not directly affect the level or function of CETP. Research in the Caucasian population found that Taq1B polymorphism 
is complete related to $-629 \mathrm{C} / \mathrm{A}$, a functional polymorphism located in the CETP gene promoter region. This promoter polymorphism has been shown affects the expression of the CETP gene and this can explain the relationship between Taq1B polymorphism, plasma CETP, and HDL-C levels [22].

In our study, bivariate analysis showed that high levels of CETP were risk factors of MS compared to CETP low levels. Multivariate analysis the relationship remained significant $(\mathrm{OR}=2.82[95 \% \mathrm{Cl} 1.07-7.41], \mathrm{p}=$ $0.036)$, despite the relationship rs 1800775 polymorphism between cases (MS obese) and non-MS obese is not significant. A study of Maroufi et al. found that CETP levels were significantly higher in the adult MS group $(1.64 \pm 0.32 \mu \mathrm{g} / \mathrm{mL})$ than healthy controls $(1.53 \pm 0.34$ $\mu \mathrm{g} / \mathrm{mL}$ ) [23]. In this study, CETP levels in MS obese groups and non-MS obese $(2.49 \pm 1.03 \mu \mathrm{g} / \mathrm{mL}$ vs. $2.04 \pm$ $0.92 \mu \mathrm{g} / \mathrm{mL}$ ) were higher than the previous studies. The previous studies have not been reported cutoff point CETP levels. In our study, cutoff point CETP levels were as follows: $\geq 2 \mu \mathrm{g} / \mathrm{mL}$ categorized as CETP high levels and $<2 \mu \mathrm{g} / \mathrm{mL}$ categorized low levels. CETP is a plasma protein that plays a role in the transport of cholesterol esters and TG between lipoprotein so that TG of VLDL or LDL will have exchange with HDL-C cholesterol ester, but the relationship between CETP gene polymorphism and CETP levels is complex and ambiguous [24]. Human CETP level and its expression are controlled by several factors, such as corticosteroids, fatty acids, cellular cholesterol levels, and transcription factors [25].

In this study, we obtained chemerin high level as a risk factor for MS compared to normal chemerin, and in multivariate analysis, this relationship remained significant $(\mathrm{OR}=2.77$ [95\% Cl 1.04-7.40], $\mathrm{p}=0.042)$. Research from Zanganeh et al. in 2016 found significant differences in serum chemerin levels between MS patients and healthy individual controls, with a mean age of 42.1 years. Significant differences were also obtained for BMI, WC, systolic and diastolic blood pressure, IR, and TG ( $p<0.001)$ [26]. In human research, chemerin is related to the development of obesity and the IR. Circulating chemerin levels increase according to the degree of obesity, marked by an increase in BMI and WC, suggesting that chemerin is related to size and adipocyte differentiation [16]. Recent studies have shown a close relationship between increased chemerin levels and changes in lipid profiles, such as each increase in TG and LDL and decreasing HDL-C levels, suggesting that chemerin can contribute to increasing atherosclerosis [27]. There are several differences in the mean serum chemerin levels of various studies and no one has mentioned the cutoff point value that divides into high and normal levels. In healthy populations, circulating serum and total plasma chemerin levels range from 90 to $200 \mathrm{\eta g} / \mathrm{mL}$ [28]. This difference may be due to differences in race or ethnic group, study population, differences in measurement devices, and protocols by different manufacturers.
There is limitation in this study that only examined 1 polymorphism (CETP -629C/A gene promoter [rs1800775]). As known, there are more than 180 SNPs in the CETP gene and 13 polymorphisms in the CETP promoter region [21], [29].

\section{Conclusion}

Based on the results of the above research, it can be concluded that high levels of serum CETP are risk factors for MS in obese adolescents and high levels of serum chemerin are risk factors for MS in obese adolescents. On the CETP -629C/A (rs1800775) gene polymorphism, AA genotype is not risk factor for MS, and based on allele, A allele carrier is not a risk factor for MS in obese adolescents.

\section{References}

1. Ogden CL, Carroll MD, Kit BK, Flegal KM. Prevalence of childhood and adult obesity in the United States, 20112012. JAMA. 2014;311(8):806-14. https://doi.org/10.1001/ jama.2014.732 PMid:24570244

2. Ogden $\mathrm{CL}$, Carroll MD, Kit BK, Flegal KM. Prevalence of obesity and trends in body mass index among US children and adolescents, 1999-2010. JAMA. 2012;307(5):483-90. https:// doi.org/10.1001/jama.2012.40

PMid:22253364

3. Kementerian Kesehatan RI. Riset Kesehatan Dasar (Riskesdas) Tahun 2013. Indonesia: Kementerian Kesehatan RI; 2013.

4. Adhianto $\mathrm{G}$, Soetjiningsih S. Prevalence and risk factors of overweight and obesity in adolescent. Paediatr Indones. 2002;42(9-10):206-11.

5. Dewi MR, Sidiartha GL. Prevalensi dan faktor risiko obesitas anak sekolah dasar di daerah urban dan rural. Medicina. 2013;44:15-21. https://doi.org/10.14710/jgi.6.2.90-93

6. Costa RF, Santos NS, Goldraich NP, Barski TF, Andrade KS, dan Kruel LF. Metabolic syndrome in obese adolescents: A comparison of three different diagnostic criteria. J Pediatr (Rio J). 2012;88(4):303-9. https://doi.org/10.2223/jped.2200 PMid:22622762

7. Pulungan AB, Puspitadewi A, Sekartini R. Prevalence of insulin resistance in obese adolescents. Paediatr Indones. 2013;53(3):167-72. https://doi.org/10.14238/pi53.3.2013.08

8. Dwipayana MP, Suastika K, Saraswati IM, Gotera W, Budhiarta AA, Sutanegara MD, et al. Prevalensi sindroma metabolik pada populasi penduduk bali, Indonesia. J Penyakit Dalam. 2011;12:1-12.

9. Carty CL, Bhattacharjee S, Haessler J, Cheng I, Hindorff LA Aroda $\mathrm{V}$, et al. Analysis of metabolic syndrome components in >15000 African Americans identifies pleiotropic variants: Results from the population architecture using genomics and epidemiology study. Circ Cardiovasc Genet. 2014;7(4):505-13. https://doi.org/10.1161/circgenetics.113.000386

PMid:25023634 
10. Zhang L, Yan F, Zhang S, Lei D, Charles MA, Cavigiolio G, et al. Structural basis of transfer between lipoproteins by cholesteryl ester transfer protein. Nat Chem Biol. 2012;8(4):342-9. https:// doi.org/10.1038/nchembio.796

PMid:22344176

11. Kwiterovich PO Jr. The metabolic pathways of high-density lipoprotein,low-density lipoprotein, and triglycerides: A current review. Am J Cardiol. 2000;86(12):5L-10. https://doi. org/10.1016/s0002-9149(00)01461-2

PMid:11374859

12. Masson $D$, Jiang $X C$, Lagrost $L$, dan Tall AR. The role of plasma lipid transfer proteins in lipoprotein metabolism and atherogenesis. J Lipid Res. 2009;50:S201-6. https://doi. org/10.1194/jlr.r800061-j|r200

PMid: 19023137

13. Chirasani VR, Revanasiddappa PD, dan Senapati S. Structural plasticity of cholesteryl ester transfer protein assists the lipid transfer activity. J Biol Chem. 2016;291(37):19462-73. https:// doi.org/10.1074/jbc.m116.744623

PMid:27445332

14. Wittamer V, Franssen JD, Vulcano M, Mirjolet JF, Le Poul E, Migeotte I, et al. Specific recruitment of antigenpresenting cells by chemerin, a novel processed ligand from human inflammatory fluids. J Exp Med. 2003;198(7):977-85. https://doi.org/10.1084/ jem.20030382

PMid:14530373

15. Mattern A, Zellmann T, Beck-Sickinger AG. Processing, signaling, and physiological function of chemerin. IUBMB Life. 2014;66(1):19-26. https://doi.org/10.1002/iub.1242

PMid:24446308

16. Goralski KB, McCarthy TC, Hanniman E, Zabel BA, Butcher EC, Parlee SD, et al. Chemerin, a novel adipokine that regulates adipogenesis and adipocyte metabolism. J Biol Chem. 2007;282(38):28175-88. https://doi.org/10.1074/jbc. m700793200 PMid:17635925

17. Li Y, Shi B, Li S. Association between serum chemerin concentrations and clinical indices in obesity or metabolic syndrome: A meta-analysis. PLoS One. 2014;9(12):e113915. https://doi.org/10.1371/journal.pone.0113915 PMid:25469985

18. Reinehr T. Metabolic syndrome in children and adolescents: A critical approach considering the interaction between pubertal stage and insulin resistance. Curr Diab Rep. 2016;16(1):1-9. https://doi.org/10.1007/s11892-015-0695-1

PMid:26747052

19. Chiarelli F, Marcovecchio ML. Insulin resistance and obesity in childhood. Eur J Endocrinol. 2008;159(1):S67-74. https://doi. org/10.1530/eje-08-0245

PMid:18805916
20. Beigh SH, Jain S. Prevalence of metabolic syndrome and gender differences. Bioinformation. 2012;8(13):613-6. https:// doi.org/10.6026/97320630008613 PMid:22829741

21. Hou H, Ma R, Guo H, He J, Hu Y, Mu L, et al. Association between six CETP polymorphisms and metabolic syndrome in uyghur adults from Xinjiang, China. Int J Environ Res Public Health. 2017;14(6):653. https://doi.org/10.3390/ijerph14060653 PMid:28629169

22. Dachet C, Poirier O, Cambien F, Chapman J, dan Rouis M. New functional promotor polymorphism, CETP/-629, in cholesteryl ester transfer protein (CETP) gene related to CETP mass and high density lipoprotein cholesterol levels: Role of Sp1/Sp3 in transcriptional regulation. Arterioscler Thromb Vasc Biol. 2000;20(2):507-15. https://doi.org/10.1161/01.atv.20.2.507 PMid: 10669650

23. Maroufi NF, Farzaneh K, Alibabrdel M, Zarei L, Cheraghi $\mathrm{O}$, Soltani $\mathrm{S}$, et al. Taq1B polymorphism of cholesteryl ester transfer protein (CETP) and its effects on the serum lipid levels in metabolic syndrome patients. Biochem Genet. 2016;54(6):894902. https://doi.org/10.1007/s10528-016-9766-5 PMid:27496123

24. Thompson JF, Lira ME, Durham LK, Clark RW, Bamberger MJ, Milos PM. Polymorphisms in the CETP gene and association with CETP mass and HDL levels. Atherosclerosis. 2003;167(2):195204. https://doi.org/10.1016/s0021-9150(03)00005-4

25. Sandhofer A, Kaser S, Ritsch A, Laimer M, Engl J, Paulweber B, et al. Cholesteryl ester transfer protein in metabolic syndrome. Obesity (Silver Spring). 2006;14(5):812-8. https://doi. org/10.1038/oby.2006.94 PMid: 16855190

26. Zanganeh SH, Roostaei F, Shafiepour MR, Mahmoodi M, Khoshdel A, dan Hajizadeh MR. Assessment of serum chemerin level in an Iranian population with metabolic syndrome and healthy individuals in 2016. JOHE. 2016;5(1):38-44.

27. Yan $Q$, Zhang $Y$, Hong J, Gu W, Dai M, Shi J, et al. The association of serum chemerin level with risk of coronary artery disease in Chinese adults. Endocrine. 2012;41(2):281-8. https:// doi.org/10.1007/s12020-011-9550-6

28. Rourke JL, Dranse HJ, Sinal CJ. Towards an integrative approach to understanding the role of chemerin in human health and disease. Obes Rev. 2013;14(3):245-62. https://doi. org/10.1111/obr.12009

PMid:23216632

29. Lu H, Inazu A, Moriyama $Y$, Higashikata $T$, Kawashiri MA, Yu W, et al. Haplotype analyses of cholesteryl ester transfer protein gene promoter: A clue to an unsolved mystery of TaqIB polymorphism. J Mol Med (Berl). 2003;81(4):246-55. https://doi. org/10.1007/s00109-002-0414-7

PMid:12700892 